Danijela MIŠIĆ

УДК $81 ’ 23: 811.111: 373.32$

Pedagogical faculty in Vranje

- стручни рад -

University in Niš

\title{
LOWER PRIMARY LEARNERS OF ENGLISH LANGUAGE AND THEIR SPEAKING SKILLS
}

\begin{abstract}
Children's speaking skills develop simultaneously with psychophysical development of a young person. Acquiring mother tongue flows very fast after the first year of life. Listening to the sounds and memorizing them creates the sound image of concepts and every concept represents linguistic treasure by using which a child communicates to the environment. In this paper the author deals with the process of developing speaking culture in foreign language learning, starting from sounds and words and going further towards the text, on the examples of short literary forms.
\end{abstract}

Key words: speaking skills, English language, primary students, linguistic treasure.

Parallel with the evolving of speaking mother tongue, preschoolers, and later on schoolchildren as well, learn the English language, by pronouncing sounds, syllables and words. The first picture books that the young recipients come in touch with represent visual image of children's world of experience, environment, school and nature. Colours, pictures and words draw children's attention, encourage imagination and speech. While stringing sounds and words gradually through adequate speaking exercises, through play, coloring and performing everyday activities, children enter the system of the English language seamlessly, which is much different from the Serbian - their mother tongue. As the result of gradual development of the English speech expression short poems are created, puzzles, stories about nature and animals, rebuses and riddles. Rhythm and melody of expression that can be heard in speaking provide the connection with musical and physical education. Free development of children's personality through drawing creations, completing sentences with new words and building up pictures, leads to a richer vocabulary of foreign language.

Goals and objectives of modern foreign language learning help in organizing teaching as a developing, individual and individualized instruction in its concept. In that way speaking level of students becomes higher, they reach aesthetics in expression and enrichment of active vocabulary.

\footnotetext{
*danijelam@pfvr.ni.ac.rs
} 
The need to speak up in another language strengthens speaking abilities. Sound realization of speech and understanding the meaning stimulates speaking skills. Students thus acquire the real meaning. Parallel with acquiring and learning speaking situations and sound images, students grasp the very essence of grammatical structure of language. At younger age, the success is greatly influenced by a well organized and systematically prepared period of oral language learning in preschool age. Well formed habits of listening and recognition of words, which are both a medium and a device for communication, also contribute to the progress of students. Mass media have big influence on the development of speaking English as the foreign language (cartoons, comics, animated fairytales in English language, picture books, plays). Except the acoustic effect, visual effect is very important; this is the reason why, except the live word, illustrative-demonstrative method and direct display in nature are very important, which put emphasis on ecological contents. And then, through questions, conversations, preparation for organized discussion, one should have in mind great diversity among students. Learning as an intellectual process requires motivation of students and creative skills of teachers. Principles, techniques and teaching aids that we use in foreign language teaching lead to students' progress that is based on raising the quality of the expression (pronunciation), building new bonds between words and sentences, creating text in oral, and later in written form, managing various speech situations, encouraging interest of students for communication, not only with the teacher, but with the class as a whole.

The abovementioned specificities of nurturing spoken culture of students during language exercises and other forms of free activities, such as theatre plays, short puppet plays, reciting poems, reading short prose texts, all these require good preparation of teachers to organize teaching and educational work. Timely and adequate emotional-psychological preparation of students to experience the foreign language and understand its meaning, make it possible for the teacher to notice differences between students in their progress, the pace of acquiring the offered linguistic material, differences in the level of knowledge and experience. Taking in consideration that mother tongue is the base for learning English as the foreign language, in the course of methodical organization of work it is important to respect individualization of learning in terms of verbal learning, solving problems, finding new models of the English linguistic system.

In order to achieve these goals, in teaching English in primary schools teachers use short literary artistic forms which emphasize the function of language learning. By investigating the teaching material, starting from preschool age until the fourth primary grade, we have discovered that poetic texts are most often used for various forms of speaking exercises because they are easy to learn, or they get melody and can be sung because their rhythm corresponds to children's nature. Short prose texts and texts in the form of dialogue are of great importance. In contemporary times, comics as combination of fine arts and literary creation draw attention and encourage thinking. Games, sayings, counting rhymes contribute to proper pronunciation, establishing balance in speech, richer lexis, respect for the specificities of the foreign language. 
With incredible speed and great ease children recognize, accept and remember sounds, voices, syllables, words, sentences while listening to their mother tongue, and thanking to their lively nature, obvious curiosity and sharp senses the children accept and acquire sounds, words and sentences they hear in the foreign - English language as well. This initial oral period is the period when children find out about new sounds that are not found in their mother tongue, such as $|\eta|,|Ә|,|æ|,|ð|$ and many other. Curriculum for young beginners in foreign language learning includes melodic poems where children pronounce sounds of the English alphabet and sing them with the melody. Various rhymes, verses, short songs attract children's attention. They learn these songs in their English classes for the first time. Organization of lessons should engage every child in listening, then repeating sounds, words and whole verses by using visual presentation. Illustrative-demonstrative method plays important role in this period of foreign language learning because children now associate sounds, voices and words with pictures that present them. Teaching material is full of colorful pictures of school, houses, nature, animals and everything in their immediate environment. These are things familiar to them, objects and concepts they know in their mother tongue, and now at the same time, they learn these concepts in the English language. Colours, images, completing pictures help children to realize the meaning in the English language. Teaching materials for preschool and the first primary grade include many exercises and activities when children use adequate colours and shapes, order pictures and objects following determined sequence, can choose among several offered options. All that strongly stimulate imagination and awareness of learning the foreign language. Recognizing objects and living beings in pictures and showing them in their natural environment when the instructor gives instructions and information in English language, answers and proper reactions to questions and tasks that connect artistic, music and physical skills and abilities, are some of the indicators of successful mastering the language of every child. A short rhyme Head and shoulders is an example for learning the names of the body parts. By using pictures and with an invitation to easy physical exercise the students are encouraged to touch their head, shoulders, eyes, ears, mouth, nose when they hear music and lyrics; this is an interesting and outstanding way to learn words and lyrics:

Head and shoulders, knees and toes,

Head and shoulders, knees and toes,

And eyes and ears and mouth and nose

Head and shoulders, knees and toes,

Knees and toes!

As they progress through the teaching material, children master the English language better and better. The subject matter becomes more complex, methods of work also change to certain degree. The children learn to understand and give answers to more complex questions related to wider environment, family, home, their own wishes and favourite games and activities. They learn the Alphabet, start writing and reading in English. At first, they learn counting rhymes which include numbers, then they learn short songs and poems by 
which the children learn to tell time and to name the objects they have in school. Here are some rhymes and short songs and poems that help the second and the third primary students to learn the mentioned subject matter:

There's one ball.

And here's one ball,

And a great, big ball I see.

Shall we count them?

Are you ready?

One, two, three!

This rhythm help children learn to count by three, but soon some other poems follow and offer the opportunity for children to acquire certain linguistic elements in creative ways, with games and songs, and to make progress in language learning. Here is an example of a song referring to the fairy tale The Little Red Riding Hood:

Who's afraid of the big, bad wolf,

Big, bad wolf, big, bad wolf.

Who's afraid of the big, bad wolf,

We're not afraid of the big, bad wolf, big, bad wolf,

Big, bad wolf, big, bad wolf.

We're not afraid of the big, bad wolf, big, bad wolf,

Tra-la-la-la-la.

The Little Red Riding Hood is one of the most favourite fairy tales which makes it an additional incentive and motive for learning English words: Little Red Riding Hood, big, bad, wolf etc. This song is very convenient for dramatization and stage, which can make children more interested and stimulate them to learn the English language and raise the level of their speaking culture.

Teaching material for primary school children include a variety of comics and drawings of animals, visits to other cities, holidays, hobbies and many other favourite activities. Some of these comics can be presented on stage as short plays and dialogues with the help of imagination and creativity.

Along with the enrichment of vocabulary, children of this age become more familiar with grammatical structure of the English language. They accomplish this through various language speaking and writing activities and exercises. These are the reading exercises and dialogue dramatization, asking questions and giving answers, solving different problems, preparing shows with singing and reciting poems and rhymes... While investigating the teaching material for the subject English language for the fourth primary grade we came across a variety of riddles and puzzles that stimulate the process of foreign language acquisition and its overall structure. Here are some examples of riddles:

- What is black when it's clean and white when it's dirty?

- Thirty white horses

(a blackboard)

Upon a white hill

Now they dance

Now they prance

Now they stand still.

(teeth) 
(breakfast and lunch)

While trying to reveal the meaning and what lies behind melodic riddles, children engage and strengthen their imagination, creativity, competitive spirit... That is why this kind of activity in English language learning has great effect on overall spiritual and linguistic development especially. In this way a child improves himself/herself in many spheres and raises his/her level of speech and knowledge.

By applying linguistic materials while playing games students develop their thinking and the learning style. The knowledge they gain in the process of foreign language learning will become a productive resource if cooperation between the teacher, chosen text and learners is correctly organized. By learning and developing linguistic ideas and processes of grammatical system the child develops the autonomy of his/her own personality and opens the way towards new values which the students will surely recognize in language learning.

\section{Literatura}

1. Carter, R. and M. McCarthy (1989) Vocabulary and Language Teaching. New York: Longman

2. Catford, J. C. (1975) "The Teaching of English as a Foreign Language“, in: The Teaching of English. Studies in Communication 3, eds Randolph Quirk and A. H. Smith, 164-189. London: Oxford University Press

3. Chomsky, N. (1968) Language and Mind. New York: Harcourt, Brace and World

4. Mišić, D. (2009) 'Udžbenici engleskog jezika u funkciji razvoja govornog i pisanog izraza i njihovo mesto u školskoj biblioteci', u Metodička praksa br. 4, str. 199-207. Vranje: Učiteljski fakultet u Vranju.

5. Gligorić, S. (2008), Ready, Steady, GO! - Pupils book (prvo izdanje 2008). Beograd: Nova škola

6. Gligorić, S. (2008), Ready, Steady, GO! - Activity book (prvo izdanje 2008). Beograd: Nova škola

7. Nenezić, Z. i Ljubinka Simidrijević (drugo izdanje 2006) Easy - Engleski jezik za 3. razred osnovne škole. Beograd: Zavod za udžbenike

8. Nenezić, Z. i Ljubinka Simidrijević (drugo izdanje 2006) Easy - Engleski jezik - Radna sveska za 3. razred osnovne škole. Beograd: Zavod za udžbenike

9. Nenezić, Z.; Simidrijević, Lj.; Dobrijević, I. (drugo izdanje 2007) Easy-Engleski jezik za 4. razred osnovne škole. Beograd: Zavod za udžbenike

10. Nenezić, Z.; Simidrijević, Lj.; Dobrijević, I. (drugo izdanje 2007) Easy-Engleski jezik - Radna sveska za 4. razred osnovne škole. Beograd: Zavod za udžbenike

11. Tomas, L. and Vicky Gil (1997) Super Me 1 - Class Book. Oxford: Oxford University Press

12. Tomas, L. and Vicky Gil (1997) Super Me 1 - Fun Book. Oxford: Oxford University Press 
13. Tomas, L. and Vicky Gil (1998) Super Me 2 - Class Book. Oxford: Oxford University Press

14. Tomas, L. and Vicky Gil (1998) Super Me 2 - Fun Book. Oxford: Oxford University Press

Данијела Мишић

$$
\begin{gathered}
\text { УЧЕНИЦИ МЛАЪИХ РАЗРЕДА ОСНОВНЕ ШКОЛЕ } \\
\text { И ЊИХОВЕ ГОВОРНЕ ВЕШТИНЕ У УЧЕЬУ ЕНГЛЕСКОГ ЈЕЗИКА }
\end{gathered}
$$

Сажетак: Развој говорних вештина деие одвија се истовремено са психо-физичким развојем младе особе. Усвајање матерњег језика тече веома брзо у првим годинама живота. Слушењем гласоваи юиховим памћењем ствара се звучна (гласовна) слика појмова, а сваки појам представља језичко благо којим дете комуничира са околином. Аутор рада се бави изучавањем процеса развоја говорне културе у учеюу страног језика, полазећи од гласова и речи па све до текста, на примерима кратких књижевних форми.

Кључне речи: говорне вештине, енглески језик. ученици основне школе, језичко благо. 